\title{
An Introduction to Foucault's Nietzschean Genealogy
}

\author{
José Nicolao Julião \\ Department of Philosophy, Federal Rural University of Rio de Janeiro, Rio de Janeiro, Brazil
}

Email address:

jnjnicolao@gmail.com

\section{To cite this article:}

José Nicolao Julião. An Introduction to Foucault's Nietzschean Genealogy. International Journal of Philosophy.

Vol. 6, No. 2, 2018, pp. 19-22. doi: 10.11648/j.ijp.20180602.11

Received: April 29, 2018; Accepted: May 25, 2018; Published: June 11, 2018

\begin{abstract}
This paper intend to demonstrate, as in Foucault, from the 1970s onwards, the archaeological question of how knowledge emerged and transformed, strongly marked by discursiveness, gave rise to the theme of why knowledge? Foucault began to worry about historical investigations about the question of power as an instrument of analysis capable of explaining the production of knowledge and which the philosopher explained in a more elaborate way in his works of Discipline and Punish (1975) and of the History of Sexuality I (1976), naming this method of genealogy of power, appropriating a Nietzschean terminology. Thus, in his 1971 essay titled, "Nietzsche, Genealogy and History" (NGH), the French philosopher, when approaching Nietzsche's On Genealogy of Morals (GM), was not only meant to understand his philosophical method, limiting himself to the function of a mere historian of philosophy, but Foucault was chiefly intending to make use of certain "torsion", which is ordinary in his interpretive strategy, to prepare in a subtle way the bases of what would become the its own method of analysis in subsequent years. Intend in this paper is to demonstrate, therefore, to what extent, the Nietzschean genealogy constitutes the basis of the genealogy of power in Foucault.
\end{abstract}

Keywords: History, Genealogy, Foucault, Nietzsche

\section{Introduction}

Foucault begins the text giving us a definition of what understands by genealogy, first, following Nietzsche who, in $G M$, contrasts your method with the method of Paul Ree and of the English Utilitarians [1]. Foucault, then, in a metaphorical language of archivist defines it as being: "Genealogy is gray, meticulous, and patiently documentary. It operates on a field of entangled and confused parchments, on documents that have been scratched over and recopied many times." [2] After that, due to the monotonous search for purpose, it ends up defining it forcefully as:

Genealogy, consequently, requires patience and knowledge of details, and it depends on a vast accumulation of source material. Its "cyclopean monuments" are constructed from "discreet and apparently insignificant truths and according to a rigorous method '; they cannot be the product of "large and well-meaning errors." In short, genealogy demands relentless erudition. Genealogy does not oppose itself to history as the lofty and profound gaze of the philosopher might compare to the molelike perspective of the scholar; on the contrary, it rejects the metahistorical deployment of ideal significations and indefinite teleologies. It opposes itself to the search for "origins." [3].

This exposed, Foucault establishes a philological distinction without the permission of Nietzsche - as is common in their interpretive 'torsions' - between Ursprung (origin) on the one hand, and Herkunft (provenance), Abkunft (descent), Entstehung (emergence, where it emerges), Geburt (birth) and Erfindung (invention) on the other hand. According to Foucault, this is the basis that allows the "genealogist" Nietzsche to put the question of origin in an adverse way from that of the great metaphysical tradition. For in Nietzsche's question of moral grounding, in $G M$, it does not concern the search for the essence, as established in the metaphysical tradition, the search for causal origin, but the search for provenance, emergence, and invention of our concepts, judgments and moral sentiments. However, it is emphasized that Foucault also draws attention to the fact that although Nietzsche, in the preface to $G M$, draws a distinction between Ursprung and Herkunft, then it returns to the equivalence between the two terms, this becomes relevant because of French philosopher not wanting to establish any dogma, no authority over the text of the German philosopher, it is only a matter of interpretive strategy. 
For Foucault, genealogist Nietzsche refuses to search for the origin understood as Ursprung, because it is metaphysical and has as its pretension to gather in it the exact essence of things, the purest possible, the identity itself, the immobile and pre-everything form which is external and from it to establish a causal relation of successiveness. Therefore, a search of the origin, in the metaphysical way, would imply trying to rediscover what was immediately the same, the Being, that is, to want to remove all the masks to reveal, in the end, a first identity, its essence in opposition to what is merely accidental and contingent. For Nietzsche genealogist, what is sure to be said is that with the metaphysical foundation, it would be unthinkable to question the provenance of most expensive and elevated moral values, for they would inhabit a place above any suspicion or questioning. In this way, to operate a genealogy of moral values, mapping their emergency foci that drive and guide the Western way of being of the human, presupposes that these supposedly untouchable, unquestionable values, which constitute the frame of what consider to be the highest and most distinctive, are also historical, contingent and casually generated, not possessing an absolute and unshakable origin. That is why, for Foucault, what is found in the historical beginning of things is not the essential identity still preserved of origin, as metaphysics intended, but, if not the discord between things, difference, nonsense, the chance, the becoming, which, consequently, leads Foucault to observe that Nietzsche prefers to listen to the historical narrative than to believe in metaphysics.

The genealogist then, in the conception of both thinkers, needs history to conjure the chimera of origin must know how to recognize the events of history, its oscillations, its surprises, being itself the body of becoming. Therefore, for Nietzsche, metaphysicians have a need to find a soul in the distant identity of the origin, while the genealogist, with his search, discovers that it was the bad calculations that gave birth to what exists and has value for us and discovers that in the root of what we know and of what we are, there subsist neither truth nor Being, but a contingently accidental exteriority.

\section{Entstehung and Herkunft Dissociated from Ursprung in Genealogy}

For Foucault, therefore, terms like Entstehung or Herkunft, dissociated from the Ursprung, characterize the word origin better, as the genealogist wants. The term Herkunft must mean provenance, that is, where it proves from things, from which root, of which race they are. It is what, according to the French philosopher, "allows dissociating the Self and making swarming in the places and corners of its synthesis, lost events." Therefore, research on provenance, unlike search for origin (Ursprung), does not seek a foundation; on the contrary, "It stirs up what is perceived immobile, it fragments what was thought united, it shows the heterogeneity of what one imagined in conformity with oneself." [4] Finally, the provenance ultimately relates to the body which is its place, this because it is the surface of inscription of events, place of dissociation of the Self, volume in perpetual pulverization. The genealogist, therefore, with the analysis of provenance, must show the body entirely marked by history, which, ruining the body with errors, brings with it also and inversely its provenance. And consequently, for Nietzsche, as Foucault points out, provenance denotes the quality of an instinct, its degree or it's fading, and the mark it leaves on the body.

Entstehung, in turn, means emergency, the point of emergence. Emergence is the entrance of forces, that is, their interpellations in a field of power struggle. It designates a place of confrontation, always taking place in the interstices of disputes. Foucault presents Nietzschean examples, showing how the emergency takes place through the entrance of forces on the scene, its interruption, the leap by which they pass from the backstage to the theater. This game of forces manifests itself through domination among the peoples, each one is manifest in a specific form, from that moment the difference of values between the men, intertwined in a game of rules created by the dominators as an attempt to maintain its the other. Thus, humanity installs each of its violence into a system of rules and proceeds from domination to domination. Consequently, the great game of history will be the one to seize the rules and thus take the place of those who use them, turning against those who used them as a form of domination and power. Thus, the becoming of humanity is a series of interpretations, and genealogy must be its history as the emergence of different interpretations.

\section{Genealogy as Effective History and Historical Sense}

Foucault, in paragraph $\mathrm{V}$ of the essay, in exposing the relations between the genealogy defined as the investigation of Herkunf and Entstehung and what is usually called by history, refers to Nietzsche's famous maxims against history and presents other terms used by the German philosopher as synonymous with genealogy, such as: effective history (wirkliche Historie), historical sense (historiche Sinn) or spirit (Geist). Nietzsche distinguishes the actual history, that is, the wirkliche Historie, from that of the historians, because it is not based on any constancy, for it is necessary to smash what allowed the comforting game of recognition, history will be effective insofar as it reintroducing the discontinuous in our own way of being. Effective history resurrects the event in what it may have as unique and acute, thus, "the forces operating in history are not controlled by destiny or regulative mechanisms, but respond to haphazard conflicts." [5] However, it is necessary, as Foucault affirms us, on the basis of paragraph 12 of the second essay of GM: "Chance is not simply the drawing of lots, but raising the stakes in every attempt to master chance through the will to power, and giving rise to the risk of an even greater chance". [6]

The "historical sense", in turn, as Foucault tell us,

Through this historical sense, knowledge is allowed to 
create its own genealogy in the act of cognition; and wirkliche Historie composes a genealogy of history as the vertical projection of its position." [7]

Foucault also shows how Nietzsche connects the "historical sense" to the history of historians, both containing in common the same beginning, impure and mixed. And from this, it establishes an analogy between Herkunft and Entstehung, the first term referring to the provenance of the historian that does not give rise to misunderstandings, that is, this provenance is of low extraction; the second term refers to the scene in which the forces take risks and face each other, that is, in which they can triumph or be confiscated, as in the nineteenth century, for example. "The historical sense", for Foucault, has three uses, namely: first, it is parody and destroyer of reality that is opposed to the theme of historyreminiscence; the second is the dissociative and destructive identity that opposes historical continuity or tradition; the third is the sacrificial and destructive use of truth that opposes history-knowledge.

On the genealogy of Nietzsche and Foucault, who criticizes historicism but still appropriates history to continue to make philosophy, it is super illuminating the seminal article by the Frankfurtian Martin Saar [8] - with whom we share the interpretation - that calls attention to the following: first in the way of specifying how genealogy includes, but also going beyond history (in the sense of writing history), it means that it writes stories of a specific type with specific interest and focus, that is, in the wide range of practices, institutions and concepts that relate to human agency, selfunderstanding and conduct. Genealogies, therefore, are especially concerned with subjections and subjections, because it is only the knowledge of these stories that provides a knowledge that can be transformed against the authorities and the cultural and social values. This method highlights a large number of genealogical treatment phenomena, but leaves others out of the picture because they are not themselves objects of a critical discussion that affects contemporary identities. Therefore, we can conclude that the genealogical method of investigating history for both Nietzsche and Foucault is not intended to rediscover the roots, that is, the origins of identity; it seeks to make appear all the discontinuities, contingencies that pervade us, constituting and transforming ourselves as subjects. "It is not a matter of finding a hidden continuity, but of knowing the transformation that made such a hurried passage possible." [9]

\section{Nietzsche's Ancestry About Foucault}

However, if there is something more general of this influence, that is, what Foucault most strongly inherits from Nietzsche, it is the extemporaneous, denunciative critical tone in 1963 when he wrote The birth of the clinic, comparing the Nietzschean criticism with that of Kant, positioning itself in favor of the first:

It may well be that we belong to an age of criticism whose lack of a primary philosophy reminds us at every moment of its reign and its fatality: an age of intelligence that keeps us irremediably at a distance from an original language. For Kant, the possibility and necessity of a critique were linked, through certain scientific contents, to the fact that there is such a thing as knowledge. In our time - and Nietzsche the philologist testifies to it - they are linked to the fact that language exists and that, in the innumerable words spoken by men-whether they are reasonable or senseless, demonstrative or poetic-a meaning has taken shape that hangs over us, leading us forward in our blindness, but awaiting in the darkness for us to attain awareness before emerging into the light of day and speaking. We are doomed historically to history, to the patient construction of discourses about discourses, and to the task of hearing what has already been said. [10]

Nevertheless, this critical tone made Nietzsche "the master of suspicion" more often than not identified with irrationalism and as the founder of postmodern thought that inspired generations of opponents of modernity, progress, reason clarity and normative morality, including among them, Foucault. Some admirers of Nietzsche, since the second half of the twentieth century, have been incisively critical of enlightening reason, and so have seen him as an ally in his struggles against "metanarratives" - in Lyotard's words. [11] It is not without purpose that Habermas takes Nietzsche as the turning point (die Drehscheibe) in modernity, which generated "an irrational, metaphysically disfigured discourse"[12], the basis of postmodernity, including among them, Foucault. Postmodern philosophers generally felt that they were witnessing the final disintegration of the European Enlightenment project, so confidently predicted by Nietzsche [13]. However, things are not so simple, as at first glance, the seductive postmodern appropriation makes us seem to rely, above all, on the works The Birth of Tragedy (work of the first phase), Thus spoke Zarathustra, Beyond Good and Evil, and $G M$ (works of the last phase), texts in which the hammer philosopher is most incisive in his "deconstruction" of the great tradition and consequently of modernity.

If take as a basis, however, the works of the intermediate phase, which include the two parts of Human, all too human, Aurora and The Gay Science (the first four parts), written and published between 1878 and 1882, one can see a Nietzsche that instead of only criticizing the Enlightenment reason see a Nietzsche who Instead of criticizing Enlightenment reason as it appears in the texts of the first and third phases, it also exalts it, using it against the feelings, the source of the creative wisdom so enthusiastically defended by Romanticism and by itself, in the first phase of its philosophy. These writings of the intermediate stage, evidently, were not Foucault's favorites - who rarely mention them - nor other representatives of postmodernity, for they saw in them the expression of Nietzsche's positivism or even a mere moment of transition between the writings of youth and maturity. But from time to time some important works have seen in these works extremely indispensable and important elements, without which the great later works would remain incomprehensible in some way and also allow us a reading that removes Nietzsche's thought from the pretense and definitive postmodern appropriation, showing that there is a 
position in his thought, more precisely in the intermediary works, that preserves the importance of the Enlightenment, therefore, there is an Enlightenment Nietzsche.

Could we analyze the postmodern interpretations of Nietzsche, especially those that have consecrated themselves and, to this day, draw crowds of supporters such as Deleuze, Derrida and, of course, Foucault to assert about them that they are mistaken and limited? Nietzsche's philosophy gives the margins of maneuvering to various interpretations and appropriations, perhaps limited, due to disregard an important part of Nietzsche's thought that clarifies to a greater extent the previous and later works and that also allows us to understand that there is also in his philosophy an exaltation of enlightening reason. However, on Foucault, a certain caveat must be made, for in the last phase of his intellectual development, in dealing with Kant's booklet, Was ist Aufklärung?, Foucault speaks of the need for a collective search for Enlightenment, although Nietzsche is not the paradigm of influence, the French thinker recognizes the need to rescue the illuminating reason. [14].

\section{Conclusion}

It is recommended that, in every conclusion, what is not presented before in the body of the text is not brought to light; then it may be concluded, on the basis of what has been shown, that in general Foucault draws inspiration from and nourishes himself with Nietzsche's philosophy, without, however, wanting to establish an interpretative dogma, thus allowing certain torsions; or even that it is constituted as the sole source of influence and inspiration. Foucault, as it is diffused, received several influences that came from French Epistemology, French Structuralism, Marx, Freud, Heidegger, the Kantian Aufklärung, etc. Perhaps, Nietzsche was the one with the greatest ascendancy over him, but not the only one, since Foucault's thought was spectral, relative and proper of variables, greatness or properties used in the description of levels of knowledge and powers, and there was no hierarchy between these levels, then, the way Foucault appropriates multiple knowledge is fundamental in formulating his formidable genealogical hypothesis.

\section{References}

[1] Nietzsche, F. Zur Genealogie der moral. In: Kritische Studienausgabe. B. 5 - Herausgegeben von G. Colli und M. Montinari. Berlin/NY: dtv/de Gruyter. 1988, 224.
[2] Foucault, Michel. "Nietzsche, genealogy and history". In Language, Counter-Memory, Practice: Selected Essays and Interviews, edited by D. F. Bouchard. Ithaca: Cornell University Press, 1977, 139.

[3] Foucault, Michel. "Nietzsche, genealogy and history". In Language, Counter-Memory, Practice: Selected Essays and Interviews, edited by D. F. Bouchard. Ithaca: Cornell University Press, 1977, 140.

[4] Foucault, Michel. "Nietzsche, genealogy and history". In Language, Counter-Memory, Practice: Selected Essays and Interviews, edited by D. F. Bouchard. Ithaca: Cornell University Press, 1977, 142.

[5] Foucault, Michel. "Nietzsche, genealogy and history". In Language, Counter-Memory, Practice: Selected Essays and Interviews, edited by D. F. Bouchard. Ithaca: Cornell University Press, 1977, 154.

[6] Foucault, Michel. "Nietzsche, genealogy and history". In Language, Counter-Memory, Practice: Selected Essays and Interviews, edited by D. F. Bouchard. Ithaca: Cornell University Press, 1977, 155.

[7] Foucault, Michel. "Nietzsche, genealogy and history". In Language, Counter-Memory, Practice: Selected Essays and Interviews, edited by D. F. Bouchard. Ithaca: Cornell University Press, 1977, 157.

[8] Saar, Martin. "Understanding genealogy: history, power, and the self". In: Journal of the Philosophy of History 2, 2008. 295-314.

[9] Foucault, Michel. A verdade e as formas Jurídicas. Rio de Janeiro: Ed. Nau. 2003, 338.

[10] Foucault, Michel. The Birth of the Clinic. An Archaeology of Medical Perception. London: Routledge. 2003, Preface, XV, XVI).

[11] Lyotard, Jean-Francois. The Postmodern Condition. Minneapolis: University of Minnesota Press, 1993, Introduction.

[12] Habermas, J. Der Philosophiche Diskurs der Moderne. Frankfurt: Suhrkamp, 1985, 117.

[13] Robinson, Dave. Nietzsche and Postmodernism. Cambridge: Icon Books, 1999, 35.

[14] Gros, Frédéric. "Foucault et la leçon kantienne des Lumières". In: Dossier Foucault et les lumières. Lumières, Numéro 8, 2006, 159-168.

[15] LEMKE, Thomas. Eine Kritik der politischen Vernunft. Foucaults Analyse der modernen Gouvernamentalität, 2. Auflage, Hamburg: Argument Verlag, 2014. 